\title{
PROGRAM PELATIHAN PERLINDUNGAN RISIKO KEBAKARAN DAERAH PEMUKIMAN PADAT PENDUDUK DI KOTA SAMARINDA
}

\section{TRAINING PROGRAM OF RISK PROTECTION FOR DENSELY POPULATED SETTLEMENT IN SAMARINDA CITY}

\author{
Deddy Alif Utama ${ }^{1}$, Sinta Ratna Dewi ${ }^{2}$ \\ ${ }^{1}$ S1 Kesehatan Lingkungan, Universitas Muhammadiyah Kalimantan Timur \\ Jl. Ir. H. Juanda No.15, Samarinda \\ 1dau475@umkt.ac.id \\ ${ }^{2}$ S1 Farmasi, 2, Universitas Muhammadiyah Kalimantan Timur \\ Jl. Ir. H. Juanda No.15, Samarinda \\ 2srd143@umkt.ac.id
}

\begin{abstract}
Abstrak
Intensitas kebakaran yang terjadi di Kota Samarinda menurut data dari dinas pemadam kebakaran cukup tinggi, yaitu sebanyak 28 kasus kebakaran (Juni-Juli 2018) dengan faktor penyebab utama adalah kelalaian warga, baik terhadap penggunaan listrik maupun kesalahan penggunaan tabung gas. Tujuan dari pengabdian ini adalah meningkatkan pengetahuan dan keterampilan masyarakat dalam penanggulangan risiko kebakaran di daerah pemukiman padat penduduk. Pengabdian ini dilaksanakan di Jl. Lambung Mangkurat Gang Masjid, Kelurahan Pelita, Kecamatan Samarinda Utara, Kota Samarinda. Sasaran pengabdian adalah warga yang berada di pemukiman padat penduduk. Kegiatan pengabdian masyarakat dilaksanakan dalam waktu satu hari melalui 3 tahap, yaitu penyuluhan, pelatihan pembuatan APAR sederhana dan praktik penggunaan APAR. Metode kegiatan yang digunakan adalah ceramah, diskusi, demonstrasi, dan praktik individu. Capaian peningkatan pengetahuan masyarakat diukur menggunakan kuesioner pretest dan posttest, dengan $p$.value $=0,000$ yaitu ada perbedaan yang siginifikan antara tingkat pengetahuan sebelum dan setelah pelatihan. Adapun peningkatan rata-rata pengetahuan masyarakat tentang penanggulangan kebakaran untuk skala rumah tangga sebelum dan setelah pelatihan adalah sebesar 35,4\%. Praktik pembuatan APAR sederhana berlangsung dengan baik dan diakhiri dengan penyerahan APAR sederhana ke masing-masing warga peserta pelatihan. Diharapkan dengan adanya program pelatihan ini, dikemudian hari akan ada tim di setiap RT yang dapat membantu menanggulangi kebakaran dan memberikan sosialisasi terhadap warga di pemukimannya terkait risiko kebakaran serta tata cara penanggulangannya.
\end{abstract}

Kata Kunci - APAR, Kebakaran, Pelatihan, Pemukiman padat

Abstract

The intensity of fires that occurred in Samarinda City according to data from the fire department was quite high, namely as much as 28 cases of fires (June-July 2018) with the main contributing factor being the negligence of residents, both to the use of electricity and the use of gas cylinders. The purpose of this service is to improve the community's knowledge and skills in managing fire risks in densely populated residential areas. This service is carried out on Jl. Lambung Mangkurat Gang Masjid, Pelita Village, North Samarinda District, Samarinda City. The target of service is residents in densely populated settlements. Community service activities are carried out in one day through 3 stages, namely counseling, training in making simple APAR and the practice of using APAR. The method of activities used are lectures, discussions, demonstrations, and individual practice. Achievements in increasing community knowledge were measured using a pretest and posttest questionnaire, with p.value $=0,000$ ie there was a significant difference between the level of knowledge before and after training. The average increase in community knowledge about fire prevention for household scale before and after training was $35.4 \%$. The practice of making simple APAR proceeded well and ended with the submission of simple APAR to each participant trainee. It is expected that with this training program, in the future there will be a team in each RT that can help tackle fires and provide socialization to residents in their settlements related to fire risk and how to overcome them.

Keywords - Fire Extinguisher, Fire, Training, Dense Settlement

\section{PENDAHULUAN}

Kebakaran mengakibatkan lebih dari 300.000 kematian setiap tahunnya dan merupakan penyebab cedera dengan jumlah terbesar ke empat di seluruh dunia (setelah kecelakaan lalu lintas, terjatuh dan kasus tenggelam[1]. Kebakaran juga dapat membuat masyarakat trauma dari segi psikologi serta terkadang merenggut korban jiwa. Dari segi ekonomi dapat berdampak terhadap pendapatan masyarakat karena apabila menimpa suatu mata pencaharian dapat menyebabkan kesenjangan sosial (Ghifary, 2014). 
Hampir 95\% kematian dan peristiwa luka bakar terjadi di negara-negara berpenghasilan rendah dan menengah, dimana tingkat kematian hampir enam kali lebih tinggi daripada negara-negara berpenghasilan menengah ke atas[2,3]. Hal tersebut disebabkan karena lebih dari separuh penduduk dunia sekarang tinggal di pusat kota dan dari populasi tersebut, beberapa diantaranya tinggal di pemukiman berpenghasilan rendah serta padat penduduk dengan dukungan yang terbatas terhadap layanan kesehatan termasuk layanan darurat terhadap peristiwa kebakaran yang sangat mudah menyebar ke lokasilokasi lainnya di daerah tersebut[4].

Seiring dengan perkembangan Kota Samarinda, kejadian kebakaran sering terjadi di ibu kota Kalimantan Timur ini. Beberapa kasus seperti pada tanggal 4 Desember 2012 di Kelurahan Baqa, Kecamatan Samarinda Seberang yang menghanguskan 68 unit rumah, menyebabkan 223 jiwa kehilangan tempat tinggal dan menelan kerugian kurang kebih 1 miliar rupiah. Peristiwa lainnya pada tanggal 30 September 2012, di Kecamatan Samarinda Ilir terjadi kebakaran yang menghanguskan sekitar 46 unit rumah yang menyebabkan 222 jiwa kehilangan tempat tinggal dengan kerugian sekitar 1,5 miliar rupiah[5]. Kedua peristiwa tersebut didukung oleh data dari BPBD Kota Samarinda, dimana sejak awal Januari hingga akhir September 2013, sebanyak 90 peristiwa kebakaran telah terjadi. Bencana kebakaran tersebut telah menyebabkan 2.112 jiwa dan 563 kepala keluarga kehilangan tempat tinggal. Data ini meningkat jika dibandingkan dengan peristiwa kebakaran periode Januari hingga September 2012 yang mencapai 73 kejadian. Tahun 2018 di Kota Samarinda, sebanyak 28 kasus kebakaran terjadi antara bulan Juni - Juli di pemukiman warga padat penduduk. Peristiwa kebakaran di pemukiman warga ini sebagian besar disebabkan karena hubungan arus pendek listrik dan akses menuju lokasi yang sulit (ASEN, 2014).

Dengan adanya kecenderungan meningkatnya kejadian kebakaran tersebut, maka dukungan sarana dan prasarana kebakaran mutlak untuk dihadirkan oleh pemerintah setempat di berbagai lokasi pemukiman termasuk di pemukiman padat penduduk. Selain itu sebagai tindakan pencegahan dan kesiapsiagaan dalam menghadapi bencana khususnya bencana kebakaran, sangat perlu dilakukan intervensi berupa pelatihan penanggulangan risiko kebakaran yang dilengkapi dengan praktik langsung, agar masyarakat dapat memahami dan memiliki soft skill dalam menanggulangi terjadinya peristiwa kebakaran.

\section{TARGET DAN LUARAN}

Secara umum tujuan kegiatan pelatihan ini adalah meningkatkan kesiapsiagaan masyarakat dalam menghadapi bencana kebakaran. Masyarakat yang menjadi target pelaksanaan adalah warga di $\mathrm{Jl}$.
Lambung Mangkurat Gang Masjid, Kota Samarinda. Hasil/luaran yang diharapkan terdiri dari dua aspek yaitu peningkatan pengetahuan dan keterampilan masyarakat terkait penanggulangan risiko kebakaran di daerah pemukiman padat penduduk.

\section{METODE PELAKSANAAN}

\section{A. Strategi}

Strategi kegiatan dalam pelaksanaan pelatihan manajemen perlindungan risiko kebakaran pada masyarakat di Jl. Lambung Mangkurat Gang Masjid, Kelurahan Pelita, Kota Samarinda adalah:

1. Pemberian materi terkait kesiapsiagaan penanggulangan bencana kebakaran

2. Pelatihan pembuatan APAR sederhana

3. Pelatihan pemadaman api skala rumah tangga dengan menggunakan cara tradisional (menggunakan kain basah) dan dengan cara modern (menggunakan alat pemadam api ringan)

Jl. Lambung Mangkurat Gang Masjid dipilih karena kasus kebakaran yang cukup besar pernah melanda daerah tersebut pada tahun 2017 sehingga sebagai salah satu upaya preventif perlu adanya pemberian pengetahuan dan pelatihan penanganan terkait kasus kebakaran kepada masyarakat guna menghindari adanya korban jiwa dan hilangnya harta benda.

\section{B. Perencanaan Kegiatan}

Berikut rancangan program pelatihan manajemen perlindungan risiko kebakaran pada masyarakat di jalan Jl. Lambung Mangkurat Gang Masjid, Kelurahan Pelita, Kota Samarinda:

TABEL I

RANCANGAN KegIATAN PROGRAM PELATIHAN

\begin{tabular}{|c|c|c|c|}
\hline $\begin{array}{l}\mathrm{N} \\
\mathrm{O}\end{array}$ & Kegiatan & $\begin{array}{c}\text { Indikator } \\
\text { keberhasilan }\end{array}$ & $\begin{array}{c}\text { Tolak ukur } \\
\text { keberhasilan }\end{array}$ \\
\hline 1. & $\begin{array}{l}\text { Pemberian } \\
\text { materi } \\
\text { penangana } \\
\text { n } \\
\text { kebakaran } \\
\text { di } \\
\text { pemukima } \\
\text { n padat } \\
\text { penduduk }\end{array}$ & \begin{tabular}{l}
\multicolumn{3}{l}{ Peningkatan } \\
pengetahuan risiko \\
kebakaran di \\
pemukiman padat \\
penduduk dan \\
penanggulanganny \\
a
\end{tabular} & $\begin{array}{l}\text { Nilai rata-rata } \\
\text { tingkat } \\
\text { pengetahuan } \\
\text { warga meningkat } \\
\text { sebesar } 30 \% \\
\text { (pretest dan } \\
\text { posttest) }\end{array}$ \\
\hline 2. & $\begin{array}{l}\text { Pelatihan } \\
\text { pembuatan } \\
\text { alat } \\
\text { pemadam } \\
\text { kebakaran } \\
\text { sederhana }\end{array}$ & $\begin{array}{l}\text { Pembuatan alat } \\
\text { pemadam } \\
\text { kebakaran } \\
\text { sederhana }\end{array}$ & $\begin{array}{l}\text { Telah } \\
\text { dilaksanakan } \\
\text { pelatihan dan } \\
\text { peserta mampu } \\
\text { mendemonstrasika } \\
\text { n pembuatan alat } \\
\text { pemadam api } \\
\text { sederhana dengan } \\
\text { peningkatan } \\
\text { keterampilan } \\
\text { sebesar 30\% } \\
\text { (sebelum dan } \\
\text { setelah pelatihan) }\end{array}$ \\
\hline
\end{tabular}




\begin{tabular}{|l|l|l|}
\hline Demonstrasi & Perbaikan dan & Peserta pelatihan \\
penanggulangan & peningkatan & mampu \\
risiko & keterampilan & mendemonstrasikan \\
kebakaran skala & penanggulangan & penanggulangan \\
rumah tangga & risiko & risiko kebakaran \\
dengan metode & kebakaran & skala rumah tangga \\
tradisional & & dengan metode \\
(APAR & & tradisional (APAR \\
sederhana) dan & & sederhana dan kain \\
modern & & basah) dan modern \\
(APAR) & & (APAR) dengan \\
& & peningkatan \\
& & keterampilan \\
& & sebesar 30\% \\
& & (sebelum dan \\
& & setelah pelatihan) \\
\hline
\end{tabular}

\section{Metode}

Metode yang digunakan dalam kegiatan program pelatihan penanggulangan kebakaran ini adalah metode ceramah, tanya jawab dan praktik. Bentuk kegiatan yang dilaksanakan dalam program pelatihan penanggulangan kebakaran adalah sebagai berikut:

1. Pretest tingkat pengetahuan dan keterampilan penanggulangan kebakaran.

2. Pemberian materi mengenai penanggulangan kejadian kebakaran skala rumah tangga.

3. Praktik pembuatan APAR sederhana.

4. Praktik pemadaman api secara tradisional dengan penggunaan kain basah dan modern dengan APAR (Alat Pemadam Api Ringan).

5. Posttest tingkat pengetahuan dan keterampilan penanggulangan kebakaran.

\section{HASIL DAN PEMBAHASAN}

Kegiatan pengabdian masyarakat ini dilakukan di Masjid Baiturrahim yang berlokasi di Jl. Lambung Mangkurat Gang Masjid, Kota Samarinda. Sasaran kegiatan adalah masyarakat yang bertempat tinggal di sekitar daerah tersebut yang berjumlah 14 orang yang berasal dari 10 RT yaitu RT 31, RT 32, RT 33, RT 39, RT 40, RT 41, RT 43, RT 44, RT 45, RT 46.

Tahap pertama kegiatan pengabdian dimulai dengan melakukan pretest mengenai tingkat pengetahuan dan keterampilan masyarakat tentang penanggulangan kebakaran untuk skala rumah tangga. Jumlah soal untuk mengetahui tingkat pengetahuan dalam pretest ini adalah 10 soal, sedangkan untuk tingkat keterampilan diukur dengan melihat tiga aspek yaitu teknik penggunaan kain basah dan alat pemadam api ringan serta keterampilan dalam pembuatan alat pemadam api sederhana.

Selanjutnya, pada tahap kedua dilakukan pemberian materi tantang penanggulangan risiko kebakaran skala rumah tangga. Materi disampaikan melalui bantuan slide powerpoint. Untuk menambah pemahaman masyarakat maka diputarkan video mengenai proses penanggulangan kebakaran dan di akhir materi dibuka sesi diskusi. Tahap ketiga yaitu praktik pembuatan alat pemadam api ringan (APAR) sederhana. Praktik dilakukan dengan tujuan mengenalkan masyarakat tentang penggunaan bahanbahan bekas yang ada disekitar kita dalam pembuatan alat pemadam api ringan. Dalam proses pembuatannya, peserta diajak berinteraksi sehingga diharapkan lebih memudahkan pemahaman peserta terhadap pembuatan APAR sederhana tersebut. Setelah pelatihan pembuatan APAR sederhana selesai, alat tersebut diberikan kepada masing-masing warga yang menjadi peserta pelatihan.

Tahap keempat, dilakukan tiga bentuk praktik pemadaman api skala kecil yaitu menggunakan kain basah, penggunaan APAR dan penggunaan APAR sederhana hasil praktik sebelumnya. Dalam pelaksanaannya, peserta memadamkan api secara bergilir satu per satu, sehingga diharapkan terjadi peningkatan keterampilan pemadaman api pada masing-masing warga. Tahap kelima, dilakukan posttest untuk mengetahui peningkatan pengetahuan dan keterampilan masyarakat tentang penanggulangan kebakaran skala rumah tangga setelah pemberian materi dan praktik. Berikut adalah hasil pretest dan posttest tingkat pengetahuan masyarakat terhadap penanggulangan risiko kebakaran untuk skala rumah tangga, tingkat keterampilan warga dalam penggunaan kain basah dan alat pemadam api ringan (APAR), dan tingkat keterampilan warga dalam pembuatan alat pemadam sederhana.

TABEL II

Proporsi TingKat PENGETAHUAN WARga TENTANG RisiKo KEBAKARAN YANG TERJADI DI JL. LAMBUNG MANGKURAT GANG MASJID

\begin{tabular}{|c|r|r|c|c|c|c|}
\hline \multirow{2}{*}{ Jenis tes } & \multicolumn{2}{|c|}{ Tingkat Pengetahuan } & \multicolumn{2}{|c|}{ Total } \\
\cline { 2 - 6 } & \multicolumn{2}{|c|}{ Baik } & \multicolumn{2}{c|}{ Rendah } & \multicolumn{2}{|c|}{} \\
\cline { 2 - 6 } & $\mathbf{n}$ & $\%$ & $\mathbf{n}$ & $\%$ & $\mathbf{n}$ & $\%$ \\
\hline Prestest & 2 & 14,3 & 12 & 85,7 & 14 & 100 \\
\hline Posttest & 12 & 85,7 & 2 & 14,3 & 14 & 100 \\
\hline
\end{tabular}

Tabel II menunjukkan bahwa dari 14 warga yang mengikuti kegiatan ini, sebesar $85,7 \%$ warga masih memiliki tingkat pengetahuan dasar yang rendah terhadap penanggulangan kebakaran skala rumah tangga. Sedangkan sisanya yaitu sebanyak 14,3\% telah memiliki tingkat pengetahuan yang baik. Berbeda dengan hal tersebut, setelah warga memperoleh materi tentang risiko kebakaran yang terjadi di pemukiman padat penduduk, sebesar $85,7 \%$ tingkat pengetahuannya berada pada kategori baik. Sedangkan sisanya yaitu sebanyak 14,3\% memiliki tingkat pengetahuan yang rendah.

Selanjutnya, karena data terdistribusi normal (p.value >0,05), maka dalam melihat adanya 
perubahan antara pengetahuan penanggulangan kebakaran untuk skala rumah tangga sebelum dan setelah pelaksanaan kegiatan pelatihan, maka dilakukan uji paired $T$ test. Dengan hasil sebagai berikut:

TABEL III

Perubahan Tingkat Pengetahuan Warga tentanc PENANGgulangan RisiKo KebaKaRAN

\begin{tabular}{|c|c|c|c|c|}
\hline \multicolumn{2}{|c|}{ Tingkat pengetahuan } & \multirow{3}{*}{$\Delta$} & \multirow{3}{*}{$\begin{array}{c}\% \\
\text { Kenaikan }\end{array}$} & \multirow{3}{*}{ p.value } \\
\hline Prestest & Posttest & & & \\
\hline$\overline{\mathbf{x}}$ & $\overline{\mathbf{x}}$ & & & \\
\hline $\begin{array}{c}4,43 \pm \\
1,089 \\
\end{array}$ & $\begin{array}{c}6,86 \pm \\
1,099 \\
\end{array}$ & $\begin{array}{c}2,429 \pm \\
0,938\end{array}$ & 54,83 & 0,000 \\
\hline
\end{tabular}

Tabel III menunjukkan bahwa nilai rata-rata tingkat pengetahuan warga sebelum dilakukan pelatihan adalah 4,43 sedangkan pada saat setelah dilakukan pelatihan meningkat menjadi 6,86. Hal ini berarti terjadi peningkatan tingkat pengetahuan ratarata warga sebesar $54,83 \%$. Nilai p.value adalah 0,000 $(<0,05)$. Sehingga dapat disimpulkan bahwa terdapat perbedaan yang signifikan antara pengetahuan penanggulangan kebakaran untuk skala rumah tangga sebelum dan setelah pelaksanaan kegiatan pelatihan.

TABEL IV

PROPORSI TINGKAT KETERAMPILAN WARGA DALAM Penggunaan Kain Basah dan Alat Pemadam Api Ringan (APAR)

\begin{tabular}{|c|c|c|c|c|c|c|}
\hline \multirow{3}{*}{$\begin{array}{c}\text { Waktu } \\
\text { Pengukuran }\end{array}$} & \multicolumn{4}{|c|}{$\begin{array}{c}\text { Tingkat Keterampilan } \\
\text { Penggunaan Kain Basah }\end{array}$} & \multirow{2}{*}{\multicolumn{2}{|c|}{ Total }} \\
\hline & \multicolumn{2}{|c|}{ Baik } & \multicolumn{2}{|c|}{ Rendah } & & \\
\hline & $\mathbf{n}$ & $\%$ & $\mathbf{n}$ & $\%$ & $\mathbf{n}$ & $\%$ \\
\hline Sebelum & 3 & 21,4 & 11 & 78,6 & 14 & 100 \\
\hline Setelah & 10 & 71,4 & 4 & 28,6 & 14 & 100 \\
\hline \multirow{3}{*}{$\begin{array}{c}\text { Waktu } \\
\text { Pengukuran }\end{array}$} & \multicolumn{4}{|c|}{$\begin{array}{c}\text { Tingkat Keterampilan } \\
\text { Penggunaan APAR }\end{array}$} & \multirow{2}{*}{\multicolumn{2}{|c|}{ Total }} \\
\hline & \multicolumn{2}{|c|}{ Baik } & \multicolumn{2}{|c|}{ Rendah } & & \\
\hline & $\mathbf{n}$ & $\%$ & $\mathbf{n}$ & $\%$ & $\mathbf{n}$ & $\%$ \\
\hline Sebelum & 6 & 42,9 & 8 & 57,1 & 14 & 100 \\
\hline Setelah & 13 & 92,9 & 1 & 7,1 & 14 & 100 \\
\hline
\end{tabular}

Tabel III menunjukkan bahwa untuk tingkat keterampilan penggunaan kain basah dalam pemadaman api, proporsi warga yang memiliki keterampilan yang baik hanya sebesar $21,4 \%$. Namun, setelah pelaksanaan pelatihan, proporsi warga yang memiliki keterampilan baik meningkat menjadi
$71,4 \%$. Peningkatan tersebut juga ditunjukkan untuk tingkat keterampilan penggunaan alat pemadam api ringan (APAR), sebelum pelaksanaan pelatihan, sebagian besar warga memiliki keterampilan yang rendah yaitu sebesar $57,1 \%$. Namun, setelah pelaksanaan pelatihan, tingkat keterampilan warga meningkat menjadi baik dengan persentase sebesar $92,9 \%$.

TABEL V

Proporsi TiNGKAT KETERAMPILAN WARgA DALAM PEMBUATAN ALAT PEMADAM SEDERHANA

\begin{tabular}{|c|c|c|c|c|c|c|}
\hline \multirow{2}{*}{$\begin{array}{c}\text { Waktu } \\
\text { Pengukuran }\end{array}$} & \multicolumn{3}{|c|}{$\begin{array}{c}\text { Tingkat Keterampilan } \\
\text { Pembuatan Alat Pemadam } \\
\text { Sederhana }\end{array}$} & \multicolumn{2}{|c|}{ Total } \\
\cline { 2 - 6 } & \multicolumn{2}{|c|}{ Baik } & \multicolumn{2}{|c|}{ Rendah } & \multicolumn{2}{|c|}{} \\
\cline { 2 - 6 } & n & \% & n & $\%$ & n & $\%$ \\
\hline Sebelum & 5 & 35,7 & 9 & 64,3 & 14 & 100 \\
\hline Setelah & 12 & 85,7 & 2 & 14,3 & 14 & 100 \\
\hline
\end{tabular}

Tabel V menunjukkan bahwa untuk tingkat keterampilan dalam pembuatan alat pemadam sederhana, sebelum pelaksanaan pelatihan, proporsi warga yang memiliki keterampilan yang baik hanya sebesar 35,7\%. Namun, setelah pelaksanaan pelatihan, proporsi warga yang memiliki keterampilan baik meningkat menjadi $85,7 \%$.

Selanjutnya, dari ketiga hasil pengukuran tingkat keterampilan tersebut, akan dilakukan uji statistik untuk mengetahui perubahan tingkat keterampilan warga tentang penggunaan kain basah untuk pemadaman api, penggunaan APAR, dan pembuatan alat pemadam sederhana, yang dapat dilihat pada tabel 6 di bawah ini:

TABEL VI

Perubahan TingKat Pengetahuan Warga tentang RISIKO KEBAKARAN YANG TERJADI

\begin{tabular}{|c|c|c|c|c|c|}
\hline $\begin{array}{c}\text { Jenis } \\
\text { Praktik }\end{array}$ & \multicolumn{2}{|c|}{ Keterampilan } & \multirow{3}{*}{$\Delta$} & \multirow{3}{*}{$\begin{array}{c}\% \\
\text { Kenaik } \\
\text { an }\end{array}$} & \multirow{3}{*}{$\begin{array}{c}\text { p.val } \\
\text { ue }\end{array}$} \\
\hline \multirow{3}{*}{$\begin{array}{c}\text { Pengguna } \\
\text { an Kain } \\
\text { Basah }\end{array}$} & $\begin{array}{c}\text { Sebelu } \\
\text { m }\end{array}$ & $\begin{array}{c}\text { Sesuda } \\
\mathbf{h}\end{array}$ & & & \\
\hline & $\overline{\mathbf{x}}$ & $\overline{\mathbf{x}}$ & & & \\
\hline & $\begin{array}{l}1,07 \pm \\
0,616\end{array}$ & $\begin{array}{l}1,71 \pm \\
0,469\end{array}$ & $\begin{array}{c}0,64 \\
\pm \\
0,74 \\
5\end{array}$ & 59.81 & 0,014 \\
\hline $\begin{array}{l}\text { Pengguna } \\
\text { an APAR }\end{array}$ & $\begin{array}{c}2,36 \pm \\
0,842\end{array}$ & $\begin{array}{c}3,50 \pm \\
0,650\end{array}$ & $\begin{array}{c}1,14 \\
\pm \\
0,66 \\
3 \\
\end{array}$ & 48,30 & 0,001 \\
\hline $\begin{array}{c}\text { Pembuata } \\
\text { n Alat } \\
\text { pemadam } \\
\text { api } \\
\text { sederhana }\end{array}$ & $\begin{array}{l}1,00 \pm \\
1,414\end{array}$ & $\begin{array}{c}2,64 \pm \\
0,745\end{array}$ & $\begin{array}{c}1,64 \\
\pm \\
1,33 \\
6\end{array}$ & 164 & 0,004 \\
\hline
\end{tabular}


Tabel VI menunjukkan bahwa untuk keterampilan penggunaan kain basah dalam pemadaman api, nilai rata-rata tingkat keterampilan warga sebelum dilakukan pelatihan adalah 1,07 sedangkan pada saat setelah dilakukan pelatihan meningkat menjadi 1,71. Hal ini berarti terjadi peningkatan tingkat keterampilan rata-rata warga sebesar $59,81 \%$. Nilai p.value adalah $0,014 \quad(<0,05)$. Sehingga dapat disimpulkan bahwa terdapat perbedaan yang signifikan antara keterampilan penggunaan kain basah untuk pemadaman api sebelum dan setelah pelaksanaan kegiatan pelatihan.

Untuk tingkat keterampilan penggunaan alat pemadam api ringan (APAR), nilai rata-rata tingkat keterampilan warga sebelum dilakukan pelatihan adalah 2,36 sedangkan pada saat setelah dilakukan pelatihan meningkat menjadi 3,50. Hal ini berarti terjadi peningkatan tingkat keterampilan rata-rata warga sebesar $48,3 \%$. Nilai p.value adalah 0,001 $(<0,05)$. Sehingga dapat disimpulkan bahwa terdapat perbedaan yang signifikan antara keterampilan penggunaan APAR sebelum dan setelah pelaksanaan kegiatan pelatihan.

Peningkatan juga ditunjukkan untuk tingkat keterampilan dalam pembuatan alat pemadam api sederhana, nilai rata-rata tingkat keterampilan warga sebelum dilakukan pelatihan adalah 1,00 sedangkan pada saat setelah dilakukan pelatihan meningkat menjadi 2,64. Hal ini berarti terjadi peningkatan tingkat keterampilan rata-rata warga sebesar $164 \%$. Nilai p.value adalah $0,004(<0,05)$. Sehingga dapat disimpulkan bahwa terdapat perbedaan yang signifikan antara keterampilan pembuatan alat pemadam api sederhana, sebelum dan setelah pelaksanaan kegiatan pelatihan.

Lebih dari setengah populasi dunia saat ini bermukim di daerah perkotaan. Sebagian besar diantaranya merupakan penduduk yang berpenghasilan menengah ke bawah. Pemilihan pemukiman tersebut tidak dilakukan berdasarkan perencanaan yang teratur namun dilakukan secara spontan. Akibatnya pemukiman yang mereka tempati terbatas dalam dukungan infrastruktur dan layanan (termasuk di dalamnya perawatan kesehatan dan layanan darurat) dan kerentanan yang lain seperti kejadian kebakaran[4] .Kebakaran dapat mudah menyebar ke lokasi-lokasi tersebut karena sejumlah faktor termasuk memasak menggunakan api terbuka, penggunaan kompor yang tidak sesuai standar, penggunaan bahan bakar yang mudah terbakar, sambungan listrik yang tidak aman, ketidaktahuan akan praktik penggunaan alat yang aman, bahan bangunan yang mudah terbakar, kepadatan bangunan yang berlebih, kurangnya hidran pasokan air dan ketidakmampuan layanan pemadam kebakaran dalam membawa peralatan pemadam karena sempitnya akses ke pemukiman[6] . Penelitian selama bertahuntahun telah menunjukkan hubungan antara insiden kebakaran dengan kondisi perumahan dan lingkungan[7,8. Kemiskinan, kebijakan sosial ekonomi, berkontribusi terhadap kualitas perumahan yang buruk dan kepadatan penduduk[9] ).

Korelasi positif juga ditemukan antara tingkat pengetahuan warga terkait penanggulangan risiko kebakaran dengan terjadinya peristiwa kebakaran. Dalam beberapa penelitian, individu yang mengetahui bahwa bahaya tersebut akan berisiko terhadap dirinya, maka akan mengambil tindakan preventif untuk menghindari bahaya tersebut $[10,11]$.

Pada dasarnya, tingkat pengetahuan sangat erat kaitannya dengan penilaian risko berbasis masyarakat. Penilaian risiko berbasis masyarakt sangat sesuai untuk diterapkan di lingkungan dimana data formal mungkin tidak tersedia, sulit untuk dikumpulkan, tidak konsisten atau berkualitas buruk. Hal ini sering terjadi sering terjadi pada beberapa kasus termasuk peristiwa kebakaran. Selain bergantung pada tingkat pengetahuan warga, penilaian risiko tersebut sangat bergantung pula pada pengalaman masyarakat setempat tentang lingkungan mereka[12.13.

Selain meningkatkan tingkat pengetahuan, pelaksanaan pendidikan dan pelatihan mutlak dilaksanakan, hal ini memiliki tujuan untuk meningkatkan kemampuan setiap individu terkait penanggulangan masalah kebakaran[14] . Walaupun perencanaan telah dibuat dengan baik, pengalaman menunjukkan bahwa banyaknya kebingungan dan kepanikan pada keadaan darurat benar-benar terjadi. Oleh karena itu, harus dilakukan latihan-latihan untuk menguji kesiapsiagaan personil dan operator dalam keadaan darurat. Latihan sebaikanya dilakukan secara berkala dengan mengikutsertakan semua unsur penangglangan keadaan darurat[15].

Penilaian risiko dan kerentanan masyarakat biasanya digunakan untuk mengidentifikasi dan memahami spektrum ancaman bahaya yang luas dan tunggal seperti potensi kebakaran yang sangat tidak bisa diprediksi dan memiliki dampak skala luas jika terjadi. Sebagai contoh, sebuah proyek yang menyelidiki kebakaran di pemukiman informal Imizamo Yethu di Cape Town, dilakukan dalam wawancara secara semi-terstruktur serta diskusi kelompok dengan berbagai anggota masyarakat dan pemangku kepentingan lokal, mengeksplorasi topiktopik berikut: penyebab, lokasi, frekuensi, dan tingkat keparahan kejadian; warga yang paling berisiko (khusus pada risiko terhadap anak-anak); strategi mengatasi; dan analisis tingkat pengetahuan serta pemahaman warga tentang risiko kebakaran dan cara menanggulanginya. Data kualitatif ini didukung dengan sensus dan bukti foto udara untuk 
memberikan informasi kuantitatif tentang populasi, perumahan, layanan, dan infrastruktur, serta analisis database untuk mengetahui tren api secara lebih faktual[16,17].

\section{SELAIN ITU, POTENSI PENGGUNAAN METODOLOGI PARTISIPATIF YANG MENYOROT APA YANG DISEBUT SEBAGAI "PLURALITAS PENGETAHUAN" DALAM MEMETAKAN SEGALA BENTUK POTENSI RISIKO DI PEMUKIMAN JUGA SEDANG DILAKUKAN DI BERBAGAI NEGARA. HAL INI DILAKUKAN SEBAGAI UPAYA PREVENTIF DAN PENINGKATAN PEMAHAMAN DAN KETERAMPILAN DALAM PROFIL RISIKO LINGKUNGAN YANG DIHADAPI DI MASA YANG AKAN DATANG[18]. KESIMPULAN}

1. Capaian peningkatan pengetahuan masyarakat diukur menggunakan kuesioner pretest dan posttest, dengan p.value $=0,000$ yaitu ada perbedaan yang siginifikan antara tingkat pengetahuan sebelum dan setelah pelatihan. Adapun peningkatan rata-rata pengetahuan masyarakat tentang penanggulangan kebakaran untuk skala rumah tangga sebelum dan setelah pelatihan adalah sebesar $54,83 \%$.

2. Terdapat perbedaan yang siginifikan antara tingkat keterampilan masyarakat dalam penggunaan APAR (p.value $=0,001$ ) dan kain basah untuk pemadaman api pada saat sebelum dan setelah pelatihan (p.value $=0,014)$. Adapun peningkatan rata-rata keterampilan masyarakat tentang kedua praktik tersebut secara berturutturut adalah sebesar $48,3 \%$ dan $59,81 \%$.

3. Terdapat perbedaan yang siginifikan antara tingkat keterampilan masyarakat dalam pembuatan alat pemadam api sederhana pada saat sebelum dan setelah pelatihan ( .value $=0,004$ ). Adapun peningkatan rata-rata keterampilan masyarakat tentang praktik tersebut adalah sebesar $164 \%$.

4. Sebagai keberlanjutan program ini, diharapkan dapat diadakan program pelatihan penanggulangan kebakaran skala rumah tangga dengan cakupan warga yang lebih luas lagi seperti diadakan dalam lingkup beberapa kelurahan maupun di lingkup beberapa kecamatan.

\section{UCAPAN TERIMA KASIH}

Ucapan terima kasih tim penulis sampaikan kepada Universitas Muhammadiyah Kalimantan Timur, Lurah Pelita dan segenap jajarannya serta warga Jl. Lambung Mangkurat, Samarinda yang telah membantu selama proses pengabdian masyarakat ini berlangsung.

\section{DAFTAR PUSTAKA}

1. Heide, E. A. 2004. Common misconceptions about disasters: Panic, the "disaster syndrome," and looting. The first 72 hours: A community approach to disaster preparedness, 337 .

2. WHO 2011. Burn prevention: success stories and lessons learned.

3. WHO 2014. Injuries and violence: the facts 2014, World Health Organization.

4. Dodman, D., Brown, D., Francis, K., Hardoy, J., Johnson, C. \& Satterthwaite, D. 2013. Understanding the nature and scale of urban risk in low-and middle-income countries and its implications for humanitarian preparedness, planning and response, International Institute for Environment and Development London.

5. Ghifary, A. 2014. Efektivitas Penggunaan Media Iklan Baliho Dalam Mensosialisasikan Bahaya Kebakaran Dikota Samarinda.

6. Twigg, J., Christie, N., Haworth, J., Osuteye, E. \& Skarlatidou, A. 2017. Improved methods for fire risk assessment in lowincome and informal settlements. International journal of environmental research and public health, 14, 139.

7. Peck, M. D., Kruger, G. E., Van Der Merwe, A. E., Godakumbura, W. \& Ahuja, R. B. 2008. Burns and fires from non-electric domestic appliances in low and middle income countries: Part I. The scope of the problem. Burns, 34, 303311.

8. Jennings, C. R. 2013. Social and economic characteristics as determinants of residential fire risk in urban neighborhoods: A review of the literature. Fire Safety Journal, 62, 13-19.

9. Murray, M. J. 2009. Fire and Ice: Unnatural Disasters and the Disposable Urban Poor in Post-Apartheid Johannesburg. International Journal of Urban and Regional Research, 33, 165192

10. Sagala, S., Wimbardana, R. \& Pratama, F. P. 2014. Perilaku Dan Kesiapsiagaan Terkait Kebakaran Pada Penghuni Permukiman Padat Kota Bandung.

11. Lindell, M. K. \& Whitney, D. J. J. R. A. 2000. Correlates of household seismic hazard adjustment adoption. 20, 13-26.

12. Kelman, I., Mercer, J. \& Gaillard, J. J. G. 2012. Indigenous knowledge and disaster risk reduction. 97.

13. Satterthwaite, D. J. D. I. E. P. E. I. D. E. G. S. L. R. D. R. D. D. 2011. What role for low-income communities in urban areas in disaster risk reduction.

14. Karimah, M., Kurniawan, B. \& Suroto, S. J. J. K. M. 2016. Analisis Upaya Penanggulangan Kebakaran di Gedung Bougenville Rumah Sakit Telogorejo Semarang. 4, 698-706.

15. Sari, L. M. 2010. Upaya pencegahan dan penanggulangan potensi bahaya kebakaran di area outer tube casting pt. Kayaba Indonesia, Bekasi Jawa Barat. Universitas Sebelas Maret.

16. Macgregor, H., Bucher, N., Durham, C., Falcao, M., Morrissey, J., Silverman, I., Smith, H. \& Taylor, A. J. D., UNIVERSITY OF CAPE TOWN, CAPE TOWN 2005. Hazard profile and vulnerability assessment for informal settlements: An Imizamo Yethu case study with special reference to the experience of children.

17. Harte, E. W., Childs, I. R. \& Hastings, P. A. J. G. R. 2009. Imizamo Yethu: A case study of community resilience to fire hazard in an informal settlement Cape Town, South Africa. 47, 142-154.

18.Twigg, J., Christie, N., Haworth, J., Osuteye, E. \& Skarlatidou, A. 2017. Improved methods for fire risk assessment in low-income and informal settlements. International journal of environmental research and public health, 14, 139.

19. Asen, C. N. 2014. Pemetaan Sebaran Pos Pemadam 